УДК 347.73:336.255.673(477)

DOI https://doi.org/10.51989/NUL.2021.6.12

\title{
ПРИНЦИП СТАБІЛЬНОСТІ НА ПЕРЕШКОДІ ЗАБЕЗПЕЧЕННЯ ЗБАЛАНСОВАНОСТІ БЮДЖЕТНИХ НАДХОДЖЕНЬ
}

\author{
Козьяков Сергій Юрійович, \\ кандидат юридичних наук, доцент, \\ доцент кафедри міжнародного приватного права \\ Інституту міжнародних відносин \\ Київського національного університету імені Тараса Шевченка
}

\section{Серьогін Олександр Юрійович,}

кандидат юридичних наук, доцент,

доцент кафедри міжнародного приватного права

Інституту міжнародних відносин

Київського національного університету імені Тараса Шевченка

У статті проаналізовано окремі положення Закону України «Про внесення змін до Податкового кодексу України та інших законодавчих актів України щодо забезпечення збалансованості бюджетних надходжень», прийнятого Верховною Радою України 30 листопада 2021 р. та більш відомого у колах науковців і юристів-практиків як законопроєкт № 5600, на предмет дотримання принципу стабільності податкового законодавства.

Дія принципу стабільності, котра виражається у тому, що будь-які нові податки та збори, їх ставки повинні передбачатися у законах і підзаконних актах, які приймаються не раніше шести місяців до початку нового бюджетного періоду, в якому нові податки та збори вступають у силу, направлена на забезпечення стабільності для платників податків шляхом надання їм розумної можливості впорядкувати свою фінансово-економічну діяльність з урахуванням очікуваного податкового навантаження.

Виходячи із приписів Конституції України, принцип верховенства права передбачає обов'язок дотримання усіх норм права, об'єктивованих у різних за правовою силою нормативно-правових актах, що забезпечується наявністю відповідних наслідків у разі недотримання таких норм. Недотримання принципу стабільності податкового законодавства має наслідком не набрання чинності змінами, які вносяться до Податкового кодексу України. Водночас, як свідчить аналіз змін до Податкового кодексу України, порушення принципу стабільності податкового законодавства $\epsilon$ сталою практикою, що призводить до виникнення податкових спорів, відсутності єдиного підходу до обов'язковості для платників податків відповідних змін, прийнятих із порушенням зазначеного принципу, та безпідставного завантаження адміністративних судів.

Наведено аналіз судової практики Верховного Суду, Касаційного адміністративного суду у складі Верховного Суду щодо вирішення подібних адміністративних спорів, відхід від якої може мати непередбачувані наслідки.

Розглянуто та науково обгрунтовано можливі шляхи розв'язання ситуації, що склалася, запропоновано варіант узгодження прийнятого Законопроєкту № 5600 із положеннями ПК України та Бюджетного кодексу України, а також зроблено прогноз перспектив можливого судового захисту з боку платників податків у досліджуваних відносинах.

Ключові слова: верховенство права, принцип стабільності, принципи податкового законодавства, податковий спір, законопроєкт № 5600, елементи податків, адміністративні суди.

Koziakov Serhii, Serohin Oleksandr. The principle of stability is an obstacle to ensuring the balance of budget revenues

The article analyzed some provisions of the Law of Ukraine "On Amendments to the Tax Code of Ukraine and Other Legislative Acts of Ukraine to Ensure Balanced Budget Revenues" adopted by the Verkhovna Rada of Ukraine on November 30, 2021, better known among scholars and legal practitioners as Draft Law № 5600, were analyzed as subject to compliance with the stability principle of tax legislation. 
The effect of the stability principle, which is expressed in the fact that any new taxes and fees, rates in laws and regulations come into force not earlier than six months before the new budget period in which the new taxes and fees adopted. Principle aimed at ensuring stability for taxpayers by giving them a reasonable opportunity to streamline their financial and economic activities taking into account the expected tax burden.

Based on the provisions of the Constitution of Ukraine, the rule of law principle implies the obligation to comply with all rules of law, objectified in different legal acts, which is ensured by the presence of appropriate consequences in case of non-compliance. Failure to comply with stability principle of tax legislation has the consequence of non-entry into force of amendments to the Tax Code of Ukraine. However, according to the analysis of amendments to the Tax Code of Ukraine, violation of stability principle of tax legislation is a constant practice that leads to tax disputes, lack of a unified approach to the obligation of taxpayers to make appropriate changes in violation of this principle, and unreasonable loading of administrative courts.

Case law approach of the Supreme Court and the Administrative Court of Cassation within the Supreme Court were analyzed, refusal from which may have unpredictable consequences.

Possible ways to resolve the situation are considered and scientifically substantiated, a variant of harmonization of the adopted Bill № 5600 with the provisions of the Tax Code of Ukraine and the Budget Code of Ukraine is proposed, and a forecast of possible judicial protection by taxpayers in the studied relations is made.

Key words: rule of law, stability principle, principles of tax law, tax dispute, bill № 5600, elements of taxes, administrative courts.

30 листопада 2021 р. Верховною Радою України був прийнятий Закон України «Про внесення змін до Податкового кодексу України та інших законодавчих актів України щодо забезпечення збалансованості бюджетних надходжень» (далі - Законопроєкт № 5600).

Допоки не буде опубліковано текст прийнятого закону, стверджувати з упевненістю, що саме було змінено чи впроваджено, важко. Водночас, виходячи з тексту Законопроєкту № 5600, підготовленого до другого читання, можна припустити, що основними положеннями закону стали:

- зменшення податкового навантаження на набувачів державної допомоги у рамках програм «Доступні кредити 5-79\%» і «Доступна іпотека 7\%»;

- збільшення екологічного податку;

- збільшення розміру ставки оподаткування за користування державними надрами та прив'язка до ринкової вартості корисних копалин.

Також передбачається підвищення низки податків, зокрема:

- акцизного податку на алкоголь;

- екологічного податку;

- рентної плати за користування частотним ресурсом;

- рентної плати за спеціальне використання води та лісових ресурсів, надрами у цілях, не пов'язаних із видобуванням корисних копалин;
- податку на доходи фізичних осіб від продажу третього і наступних об'єктів нерухомого майна.

Базовою датою набуття чинності закону Законопроєкт № 5600 передбачав 01 січня 2022 p.

Тобто, незважаючи на добрі наміри законотворців якнайшвидше наповнити бюджети усіх рівнів, із прикрістю можна констатувати, що прийнятий Законопроект № 5600 вкотре буде порушувати низку принципів податкового законодавства, закріплених у ст. 4 Податкового кодексу України (далі - ПК України), зокрема принцип стабільності.

Питанням дотримання вимог законодавства під час прийняття та застосування законів із питань оподаткування в Україні приділялася увага у численних працях і правових висновках М.П. Кучерявенко, Д.В. Приймаченко, особливо зосереджував увагу на дослідженні принципу стабільності Р.Г. Браславський та інші вчені.

Метою статті $\epsilon$ дослідження особливостей дії принципу стабільності, аналіз судової практики та перспектив можливого судового захисту прав платників податків, а також формулювання науково обґрунтованих висновків щодо виправлення ситуації, яка виникла після прийняття Законопроєкту № 5600 Верховною Радою України.

Відтермінування моменту набрання чинності закону, котрим змінюються елементи 
податків і зборів, слід розуміти як гарантію, яка надається державою платнику податків для цілей податкового планування, передбачуваності податкового законодавства. Затримка моменту набрання чинності закону у цьому разі $\epsilon$ гарантією належного виконання платниками податкового обов'язку. Стабільність елементів податків і зборів забезпечує стале джерело доходів бюджетів різних рівнів.

Конституція України, встановлюючи обов'язок щодо сплати податків і зборів, визначає обов'язкову форму до акта, яким закріплюється податковий обов'язок. Податки та збори можуть бути встановлені виключно законом. До вимог законно встановленого податку та збору належать: вимога до форми акта; вимога до процедури прийняття акта; вимога до змісту акта; вимога до порядку введення в дію.

Дотримання принципів, що визначають особливості нормотворчих процедур у певній галузі права та встановлені у галузевому законодавчому акті, $\epsilon$ наслідком панування принципу верховенства права й утвердження на території держави такого правового режиму, який унеможливлює зловживання через недотримання імперативних норм i, як наслідок, порушення прав учасників відповідних відносин.

Порушення принципу стабільності податкового законодавства $\epsilon$ проявом неповаги до правової системи держави та права загалом як об'єктивного критерію оцінки досягнутого культурного рівня суспільства.

Безпосередньо принцип стабільності закріплений у пп. 4.1.9 п. 4.1. ст. 4 ПК України та передбачає, що зміни до будь-яких елементів податків і зборів не можуть вноситися пізніш як за шість місяців до початку нового бюджетного періоду, у якому будуть діяти нові правила та ставки. Податки та збори, їх ставки, а також податкові пільги не можуть змінюватися протягом бюджетного року.

Тобто дія принципу стабільності окреслюється у двох аспектах: по-перше, у тому, що будь-які нові податки та збори, їх ставки повинні впроваджуватися законами у ПК України не раніше шести місяців до початку нового бюджетного періоду, у якому нові податки та збори почнуть діяти, а по-друге, зміна податків не може відбуватися протягом бюджетного року, тобто з 01 січня по 31 грудня поточного року.

Окрім цього, ч. 3 ст. 27 Бюджетного кодексу України закріплює, що Закони України або їх окремі положення, які впливають на показники бюджету (зменшують надходження бюджету та/або збільшують витрати бюджету), приймаються:

- не пізніше 15 липня року, що передує плановому, вводяться в дію не раніше початку планового бюджетного періоду;

- після 15 липня року, який передує плановому, вводяться у дію не раніше початку бюджетного періоду, що настає за плановим.

Подібне положення містить ПК України і щодо порядку оприлюднення рішень органів місцевого самоврядування, якими впроваджуються нові місцеві податки або змінюються вже наявні. Так, у пп. 12.3.4 п. 12.3 ст. 12 ПК України передбачено, що рішення про встановлення місцевих податків і зборів офіційно оприлюднюється відповідним органом місцевого самоврядування до 25 липня року, що передує бюджетному періоду, у якому планується застосовування встановлюваних місцевих податків та/або зборів або змін (плановий період). В іншому разі норми відповідних рішень застосовуються не раніше початку бюджетного періоду, що настає за плановим періодом.

Таким чином, як щодо загальнодержавних податків, так і щодо місцевих податків ПК України містить однаковий підхід (принцип стабільності) щодо встановлення податків, зборів та обов'язкових платежів.

Слід зазначити, що вказаний підхід щодо застосування принципу стабільності було підтверджено численною судової практикою як щодо загальнодержавних, так і щодо місцевих податків.

У контексті застосування принципу стабільності у впровадженні загальнодержавних податків рішення судів ухвалювалися, зокрема, у справах № 816/844/16, № 816/846/16, № 826/3644/17 та ін.

Судами у цих справах, на прикладі справи № 816/844/16, встановлено, що:

- Предметом розгляду є питання правомірності визначення позивачу податкового зобов'язання за платежем рентна плата за 
користування надрами для видобування природного газу за 4 квартал 2015 р. з урахуванням ставки рентної плати за користування надрами для видобування корисних копалин, а саме газу природного (будь-якого походження) з покладів, які повністю або частково залягають на глибині до 5000 метрів, у розмірі 55\% від вартості товарної продукції гірничого підприємства.

- Законом № 1621-VII було змінено розмір ставок плати за користування надрами для видобування корисних копалин щодо газу природного (будь-якого походження) з покладів, що повністю або частково залягають на глибині до 5000 метрів, із $28 \%$ до $55 \%$ на період із 3 серпня 2014 до 1 січня 2015 pp.

- Законом № 71-VIII, який набрав чинності 1 січня 2015 р., внесено зміни до ПК України, відповідно до яких загальнодержавний платіж у вигляді плати за користування надрами для видобування корисних копалин і плати за користування надрами у цілях, не пов'язаних із видобуванням корисних копалин, трансформовано в рентну плату, до складу якої входить рентна плата за користування надрами для видобування корисних копалин.

- Законом № 1621-VII (набрав чинності 3 серпня 2014 р.) було збільшено ставки плати за користування надрами, але без внесення будь-яких змін (доповнень) безпосередньо до пп. 263.9.1 п. 263.9 ст. 263 ПК України; відповідно ж до змін, внесених Законом № 71-VIII (набрав чинності 1 січня 2015 р.), ставки рентної плати за користування надрами для видобування корисних копалин закріплено у ст. 252 ПК України.

- Згідно із п. 252.20 ст. 252 ПК України (у редакції Закону № 71-VIII) ставки рентної плати за користування надрами для видобування корисних копалин установлюються у відсотках від вартості товарної продукції гірничого підприємства - видобутої корисної копалини (мінеральної сировини), зокрема газу природного (будьякого походження) з покладів, які повністю або частково залягають на глибині до 5000 метрів, 55\% від вартості товарної продукції гірничого підприємства.

Отже, внесеними до законодавства змінами збільшено ставку податку із $28 \%$ до
55\% від вартості товарної продукції гірничого підприємства.

Верховний Суд раніше вже вирішував питання про усунення розбіжностей у застосуванні згаданих вище норм податкового законодавства у контексті аналогічних за своїм змістом правовідносин. Зокрема, у своїй постанові від 17 березня 2021 р. по справі № 816/846/16 Верховний Суд сформулював правовий висновок про те, що, оскільки Закон № 1621-VII було прийнято 31 липня 2014 р. (набрав чинності 3 серпня 2014 р.), тобто за 5 місяців до початку нового бюджетного періоду (2015 р.), а Закон № 71-VIII (набрав чинності 1 січня 2015 р.) - 28 грудня 2014 р., тобто за 3 дні до початку нового бюджетного періоду, яким $€ 2015$ рік, то історичний і нормативний підхід до розуміння положень ст. 252 ПК України, зокрема її п. 252.20, дає підстави вважати, що зміни до ставок податку (збору), внесені Законами № 1621-VII та № 71-VIII у 2014 р. менш, ніж за шість місяців до початку нового бюджетного періоду (2015р.), можуть застосовуватися відповідно до принципу стабільності оподаткування лише з нового бюджетного періоду, тобто із 2016 р. Саме у такому разі буде виконано умову пп. 4.1.9 п. 4.1 ст. 4 ПК України, відповідно до якої зміни до будь-яких елементів податків і зборів не можуть вноситися пізніш як за шість місяців до початку нового бюджетного періоду, у якому будуть діяти нові правила та ставки, тобто дотримано принцип стабільності податкових відносин.

На практиці було застосовано принцип стабільності й у контексті впровадження місцевих податків, зокрема правозастосовний приклад наведено у рішеннях судів у справах № 820/6284/16, № 804/1473/17, № $806 / 622 / 16$, № $826 / 11330 / 16$ та № 820/1198/16.

Так, у рішенні касаційного суду у справі № 820/6284/16 зазначено, що, «враховуючи ухвалення Закону України № 71-VIII "Про внесення змін до Податкового кодексу України та деяких законодавчих актів України щодо податкової реформи", яким викладена у новій редакції ст. 267 ПК України та запроваджено транспортний податок в Україні, лише 28 грудня 2014 р., а також відсутність доказів прий- 
няття відповідною місцевою радою за місцем проживання позивача рішення про встановлення транспортного податку до 15 липня 2014 р., касаційний суд доходить висновку, що застосування контролюючим органом положень ст. 267 ПК України з метою оподаткування транспортним податком можливо було не раніше наступного бюджетного періоду, який настав за плановим (2015р.), тобто не раніше 2016 р.».

Слід також зазначити, що Головне юридичне управління Апарату Верховної Ради України в своїх Запереченнях до Законопроєкту № 5600 також підкреслювало, що вказаний Законопроєкт порушує наведений основний принцип податкового законодавства - принцип стабільності.

У п. 14 Заперечень встановлено, що п. 1 Прикінцевих положень проекту, яким передбачається набрання ним чинності з 1 січня 2022 р., не відповідає принципу стабільності податкового законодавства, встановленому пп. 4.1.9 п. 4.1 ст. 4 ПК України, згідно з яким зміни до будь-яких елементів податків і зборів не можуть вноситися пізніш як за шість місяців до початку нового бюджетного періоду, у якому будуть діяти нові правила та ставки. Податки та збори, їх ставки, а також податкові пільги не можуть змінюватися протягом бюджетного року.

Крім того, зазначене не узгоджується з ч. 3 ст. 27 Бюджетного кодексу України, згідно з якою закони України або їх окремі положення, що впливають на показники бюджету (зменшують надходження бюджету та/або збільшують витрати бюджету) і приймаються не пізніше 15 липня року, що передує плановому, вводяться в дію не раніше початку планового бюджетного періоду.

Висновки. Прийнятий Законопроект № 5600, якщо Верховна Рада України не змінить дату набуття чинності (01 січня 2022 р.), буде грубо порушувати положення ст. 4 ПК України та ст. 27 Бюджетного кодексу України щодо основоположного принципу оподаткування.

Цілком імовірним наслідком порушення принципу стабільності у разі нарахування податковими органами на його основі податкових зобов'язань платникам податків буде ініціювання судових процедур платниками податків щодо оскарження вказаних нарахувань.

Враховуючи наведену вище судову практику Касаційного адміністративного суду у складі Верховного Суду, з упевненістю можна стверджувати про велику вірогідність винесення рішень судами на користь платників податків.

Ще одним варіантом узгодження прийнятого Законопроєкту № 5600 із положеннями ПК України та Бюджетного кодексу України $€$ відтермінування моменту введення Законопроєкту № 5600 у дію до 01 січня 2023 р., однак з огляду на те, що законопроект направлений на наповнення бюджету вже у 2022 р., не слід очікувати відтермінування задекларованої дати набуття Законопроектом № 5600 чинності.

Також слід зазначити, що відповідно до п. 7.3 ст. 7 ПК України будь-які питання щодо оподаткування регулюються цим Кодексом і не можуть встановлюватися або змінюватися іншими законами України, крім законів, що містять виключно положення щодо внесення змін до цього Кодексу та/або положення, які встановлюють відповідальність за порушення норм податкового законодавства.

Із Законопроєкту № 5600 вбачається, що зміни планується впровадити не тільки до ПК України, а й до низки інших Законів і Кодексів України.

Відповідне порушення ст. 7 ПК України у разі прийняття Верховною Радою України Законопроекту № 5600 може також мати наслідки ініціювання Платниками податків потенційних судових справ щодо оскарження нарахованих податків на цій основі.

Так, у справі № 826/18764/15 Вищій адміністративний суд України звернув на це увагу та зазначив, що «відповідно до п. 7.3 та п. 7.4 ст. 7 Податкового кодексу України будь-які питання щодо оподаткування регулюються цим Кодексом і не можуть встановлюватися або змінюватися іншими законами України, крім законів, що містять виключно положення щодо внесення змін до цього Кодексу та/або положення, які встановлюють відповідальність за порушення норм податкового законодавства. <...> Судами попередніх інстанцій встановлено, що Законом № 1621-VII не вносилися зміни виключно до Податкового кодексу України». 
Вказана обставина не останньою чергою стала підставою для скасування податкових повідомлень-рішень, зокрема у справі № 826/18764/15.

За таких обставин, підсумовуючи неведене, варто зазначити, що для мінімізації ризиків оскарження платниками податків нарахованих сум податкових зобов'язань, визначених на підставі Законопроєкту № 5600, і з метою досягнення дійсної збалансованості бюджетних надходжень варто впроваджувати вказаний Законопроєкт № 5600 із чітким дотриманням основних принципів податкового законодавства.

\section{ЛITEPATУPA:}

1. Податковий кодекс України. Відомості Верховної Ради України. 2011. № 13-14, № 15-16, № 17. Ст. 112.

2. Кучерявенко М.П. Законопроєкт 5600 порушує принцип стабільності. URL: https:// kucheryavenko.com.ua/zakonoproekt-5600-porushuye-prynczyp-stabilnosti/ (дата звернення: 01.12.2021).

3. Браславський Р.Г. Принцип стабільності та його місце в нормотворчій діяльності у сфері оподаткування. Підприємництво, господарство і право. 2017. № 11. С. 138-142.

4. Браславський Р.Г. Вплив принципу стабільності на регламентацію відносин у податково-правовій сфері. Прикарпатський юридичний вісник. 2017. № 4. С. 39-42.

5. Браславський Р.Г. Принципи податкового права : автореф. дис. ... докт. юрид. наук : 12.00.07. Запоріжжя, 2019. 41 с. URL: http://phd.znu.edu.ua/page//aref/07_2019/braslavs-kii--_avtoreferat.pdf (дата звернення 01.12.2021). 